\title{
DINAMIKA PENGELOLAAN BARANG MILIK NEGARA BERWAWASAN GENDER (STUDI KASUS KANTOR PELAYANAN KEKAYAAN dan LELANG SURAKARTA)
}

\author{
Shafira Zahdanti ${ }^{1}$ dan Taufik Raharjo ${ }^{2^{*}}$ \\ Politeknik Keuangan Negara STAN \\ E-mail : taufik.raharjo@pknstan.ac.id
}

INFORMASI ARTIKEL

ABSTRAK

Diterima Pertama

[ 28 Mei 2021]

Dinyatakan Diterima

[24 Juli 2021]

Kata Kunci:

Pengelolaan, Barang Milik Negara, Kesetaraan Gender.
This study aims to determine the dynamics in the implementation and constraints of BMN management from a gender perspective. This research is a qualitative study with data collection through observation and interviews at the Surakarta State Property and Auction Service Office. The results of this study reveal that the office has implemented the management of State Property that supports gender equality and has a positive impact on all parties. However, there are several obstacles in this management, namely the lack of commitment, planning policies, institutions, human resources, budgeting, and community participation.

Penelitian ini bertujuan untuk mengetahui dinamika dalam implementasi serta kendala pengelolaan BMN yang berwawasan gender. Penelitian ini merupakan studi kualitatif dengan pengumpulan data melalui metode observasi dan wawancara di Kantor Pelayanan Kekayaan Negara dan Lelang Surakarta. Hasil penelitian ini mengungkapkan bahwa kantor tersebut telah mengimplementasikan pengelolaan Barang Milik Negara yang mendukung kesetaraan gender dan mempunyai dampak positif dari semua pihak. Namun terdapat beberapa kendala dalam pengelolaan ini, yaitu kurangnya komitmen, kebijakan perencanaan, kelembagaan, Sumber Daya Manusia, penganggaran, dan partisipasi masyarakat. 
DINAMIKA PENGELOLAAN BARANG MILIK NEGARA BERWAWASAN GENDER (STUDI KASUS KANTOR PELAYANAN KEKAYAAN dan LEKANG SURAKARTA)

Shafira Zahdanti ${ }^{1}$ dan Taufik Raharjo ${ }^{2}$

\section{PENDAHULUAN}

\subsection{Latar Belakang}

Kesetaraan gender merupakan sebuah isu yang senantiasa berdengung dalam kehidupan manusia modern. Walaupun isu kesetaraan gender ini sudah menyeruak cukup lama tapi hingga saat ini isu tersebut masih sangat relevan untuk dibahas. Hal ini dikarenakan masih banyaknya terjadi diskriminasi berdasar gender di dalam kehidupan. Harus kita sepakati memang budaya patriarki mengakar sangat lama dalam perjalanan kehidupan manusia hingga budaya itu menjadi sebuah cara pandang manusia terhadap gender. Dalam hal ini secara umum perempuan akan menjadi korban dari cara pandang tersebut. Manusia modern terus melakukan upaya untuk merubah budaya tersebut, karena tidak selayaknya peran dan status dalam kehidupan manusia hanya didasarkan pada perbedaan gender.

Upaya untuk tercapainya kesetaraan dan keadilan gender memerlukan intervensi pemerintah untuk mempercepat tercapainya hal tersebut, yang hal itu diimplementasikan dengan membentuk suatu kebijakan yang disebut Strategi Pengarusutamaan Gender (PUG). Istilah pengarusutamaan gender berasal dari bahasa Inggris "Gender Mainstreaming". Istilah ini digunakan pada saat Konferensi Wanita Sedunia ke IV di Beijing Tahun 1995 dan dicantumkan pada "Beijing Platform of Action". Semua negara peserta termasuk Indonesia dan organisasi yang hadir pada konferensi tersebut secara eksplisit menerima mandat untuk mengimplementasikan "Gender Mainstreaming" tersebut di negaranya masing-masing.

Berdasarkan Instruksi Presiden Nomor 9 Tahun 2000, pengarusutamaan gender dalam pembangunan nasional dilakukan guna terselenggaranya perencanaan, penyusunan, pelaksanaan, pemantauan, dan evaluasi atas kebijakan dan program pembangunan nasional yang berperspektif gender sesuai dengan bidang, tugas, dan fungsi, serta kewenangan masingmasing. Strategi pembangunan ini dilakukan melalui kebijakan dan program yang memperhatikan pengalaman, aspirasi, kebutuhan, dan permasalahan ke dalam proses perencanaan, pelaksanaan, pemantauan, dan evaluasi.

Kementerian Keuangan sebagai bagian dari pemerintahan turut menyelenggarakan strategi PUG dengan tujuan, sasaran, dasar hukum, hingga konsep gender. Salah satu implementasi dari strategi PUG adalah melalui pengelolaan Barang
Milik Negara (BMN), seperti toilet terpisah laki-laki dan perempuan, tempat parkir khusus ibu hamil, tangga ramah perempuan, juga termasuk tempat parkir khusus lansia dan difabel, serta jalur ramah difabilitas.

Karenanya menjadi hal yang menarik untuk dibahas tentang implementasi serta kendala dari strategi PUG ini di lapangan. Sehingga penelitian ini bertujuan untuk mengetahui dinamika dalam implementasi serta kendala pengelolaan BMN yang berwawasan gender. Penelitian ini dilakukan di Kantor Pelayanan Kekayaan Negara dan Lelang (KPKNL) Surakarta yang berada di bawah Direktorat Jenderal Kekayaan Negara (DJKN) Kantor Wilayah Jawa Tengah dan DI Yogyakarta. DJKN merupakan salah satu eselon satu di Kementerian Keuangan.

\section{KERANGKA TEORI}

\subsection{Konsep Kesetaraan Gender}

Perbedaan gender antara laki-laki dan perempuan selama ini lebih lekat dipandang dari aspek yang terlihat, yaitu fisik dan anatomi. Djoharwinarlien, 2012 yang sependapat dengan Glynos (2000) menjelaskan bahwa penyebutan atas perbedaan tersebut berlangsung melalui proses narasi dan penafsiran sehingga muncul konstruksi sosial tertentu, yang secara resiprokal mempengaruhi terciptanya suatu sistem yang membedakan posisi perempuan dalam masyarakat. Vasiljevic (2017) yang sependapat dengan Beauvoir (1972) mengungkapkan bahwa perempuan dan laki-laki memiliki peranan dengan status sosial yang berbeda dengan laki-laki sehingga ketimpangan gender menjadi salah satu alasan bahwa dalam relasi gender terdapat suatu kondisi perempuan dianggap inferior.

Terdapat tiga teori utama yang ditulis Utaminingsih (2017) mengenai kajian analisis gender, yaitu: Teori Nature, Teori Nurture, dan Teori Equilibrium. Teori Nature mengungkapkan bahwa pembedaan yang terjadi antara peran laki-laki dan perempuan bersifat alami, kodrati, atau "sabda alam". Laki-laki disebut memiliki peran utama atau ordinat. Sedangkan perempuan dipandang sebagai pihak subordinat karena memiliki ruang gerak yang terbatas disebabkan kehamilan, proses melahirkan, dan menyusui. Perbedaan struktur fungsional berdampak pada strata sosial berlaku pada masyarakat patriarki. Teori nurture memiliki anggapan bahwa perbedaan peran sosial yang terbentuk mengenai gender bukanlah diakibatkan doktrin keagamaan atau determinasi anatomi biologi, melainkan dampak dari hasil rekayasa konstruksi sosial budaya. Teori equilibrium 
DINAMIKA PENGELOLAAN BARANG MILIK NEGARA BERWAWASAN GENDER (STUDI KASUS KANTOR PELAYANAN KEKAYAAN dan LEKANG SURAKARTA)

Shafira Zahdanti ${ }^{1}$ dan Taufik Raharjo ${ }^{2}$

menyatakan bahwa hubungan gender masih bersifat kompromi atas terjadinya pembedaan peran antara laki-laki dan perempuan. Pada dasarnya itu tidak menjadi masalah apabila tidak menimbulkan penindasan, kekerasan, atau pemaksaan. Sayangnya, realita justru kemudian membentuk sebagai apa yang dianggap ketidakadilan gender.

Gerakan feminisme kemudian hadir dengan tujuan menghapus diskriminasi yang kerap dialami perempuan. Tidak hanya menimbulkan dampak bagi individu, ketidaksetaraan menimbulkan dampak yang sangat luas dan kompleks. Walaupun pada realitanya, terdapat beberapa kategori gerakan feminis berdasarkan basis ideologi masing-masing tapi secara umum feminisme mendukung kaum perempuan agar tidak dijajah dan bebas akan haknya yang berawal dari membuka cakrawala wawasan perempuan.

\subsection{Konsep Dasar Inklusivitas}

Konsep inklusif erat hubungannya dengan social exclusion. Levitas (2007) dalam Social Exclusion Unit, mendefinisikan ekslusi sosial sebagai suatu keadaan ketika seseorang menderita akibat suatu masalah yang kompleks atau saling berhubungan, seperti pengangguran, minim kemampuan, dan kesehatan yang buruk. Permasalahan tersebut menuntun kepada arah seseorang dapat tereksklusikan atau mengekslusikan diri dari lingkungannya. Hayes (2008) mengungkapkan bahwa eksklusi sosial bergantung kepada norma dan ekspektasi dari lingkungan pada kurun waktu tertentu. Dalam hal ini dapat berakibat suatu kelompok atau individu menjadi terhalang aksesnya untuk meraih kesempatan berpartisipasi.

Ruman (2014) menjelaskan bahwa bentuk-bentuk eksklusi sosial dibagi menjadi empat, yaitu eksklusi dari hak formal sebagai warga negara, eksklusi dari pasar pekerja, eksklusi dari partisipasi sebagai masyarakat sipil, dan eksklusi dari arena sosial. Suatu kebijakan dapat menyebabkan eksklusif bagi beberapa kelompok, sehingga disebut sebagai kebijakan yang inklusif sebagian.

Dan implementasi dari PUG tidak hanya mengenai kesetaraan gender. Inklusivitas termasuk dalam kategori PUG, antara lain melalui dukungan sarana prasarana fisik seperti nursery room, toilet terpisah antara laki-laki dan perempuan, mushola terpisah dan ramah disabilitas, dan parkir prioritas ibu hamil, lansia, dan difabel.

Pencapaian suatu lingkungan yang inklusif bagi semua orang membawa dampak yang besar bagi seluruh spektrum kehdupan. Dalam rangka pencapaian wilayah yang mendukung inklusivitas, perlu dorongan yang lebih besar terhadap kesetaraan dengan mengatasi kekurangan dan pemenuhan hak individu atau kelompok oleh masyarakat yang kohesif serta kebijakan pemerintah yang kuat.

\subsection{Konsep Barang Milik Negara (BMN)}

Barang Milik Negara (BMN) merupakan seluruh barang yang diperoleh atau dibeli menggunakan Anggaran Pendapatan dan Belanja Negara (APBN) atau cara perolehan lainnya yang sah. Sebagai aset pemerintah, BMN dapat dikelola sendiri oleh pemerintah pada pengelola barang, pengguna barang, dan kuasa pengguna barang atau dikelola oleh pihak lain (Peraturan Pemerintah Nomor 28 Tahun 2020 dan UU No 1 Tahun 2004).

Wujud BMN dapat berupa persediaan, tanah, gedung dan bangunan, jalan, irigasi, jaringan, aset tetap, konstruksi dalam pengerjaan, aset tak berwujud, maupun aset kemitraan. Sebelum pengadaan BMN tanah dan bangunan, rencana pengadaan berpedoman pada Peraturan mengenai standar barang dan standar kebutuhan BMN, termasuk BMN yang mendukung PUG

\section{METODE PENELITIAN}

Penelitian ini menggunakan metode penelitian kualitatif, yaitu mencoba memahami fenomena yang sedang terjadi, baik dari sisi sikap, dan tindakan. Pengumpulan data dilakukan dengan melakukan observasi dan wawancara. Observasi dilakukan pada penggunaan objek-objek pengarusutamaan gender BMN yang terdapat pada KPKNL Surakarta secara langsung. Sedangkan wawancara yang diartikan sebagai proses memperoleh informasi untuk tujuan penelitian melalui tanya jawab tatap muka antara pewawancara dan narasumber menggunakan peralatan tertentu (Edi, 2016) dilakukan kepada 7 orang narasumber.

Tabel 1 Daftar Narasumber

\begin{tabular}{|c|l|}
\hline Kode & \multicolumn{1}{|c|}{ Jabatan Narasumber } \\
\hline Narasumber 1 & $\begin{array}{l}\text { Ketua Tim PUG Kanwil DJKN } \\
\text { Jateng dan DIY }\end{array}$ \\
\hline
\end{tabular}


DINAMIKA PENGELOLAAN BARANG MILIK NEGARA BERWAWASAN GENDER (STUDI KASUS KANTOR PELAYANAN KEKAYAAN dan LEKANG SURAKARTA)

Shafira Zahdanti ${ }^{1}$ dan Taufik Raharjo ${ }^{2}$

\begin{tabular}{|c|l|}
\hline Narasumber 2 & $\begin{array}{l}\text { Pegawai Bagian Umum KPKNL } \\
\text { Surakarta }\end{array}$ \\
\hline Narasumber 3 & $\begin{array}{l}\text { Pegawai Seksi Lelang KPKNL } \\
\text { Surakarta }\end{array}$ \\
\hline Narasumber 4 & $\begin{array}{l}\text { Pegawai Bagian Umum KPKNL } \\
\text { Surakarta }\end{array}$ \\
\hline Narasumber 5 & $\begin{array}{l}\text { Pegawai Seksi Kepatuhan } \\
\text { Internal KPKNL Surakarta }\end{array}$ \\
\hline Narasumber 6 & $\begin{array}{l}\text { Pegawai Seksi Lelang KPKNL } \\
\text { Surakarta }\end{array}$ \\
\hline Narasumber 7 & $\begin{array}{l}\text { Pegawai Seksi Piutang Negara } \\
\text { KPKNL Surakarta }\end{array}$ \\
\hline
\end{tabular}

\section{HASIL PENELITIAN}

\subsection{Implementasi PUG Melalui BMN di KPKNL Surakarta}

Berdasarkan hasil observasi, melalui brosur yang terdapat di KPKNL Surakarta, instansi ini mendefinisikan gender sebagai perbedaan peran dan tanggung jawab perempuan dan laki-laki dibentuk/dikonstruksikan oleh masyarakat (diharapkan, diajarkan, disosialisasikan oleh keluarga dan masyarakat) dan bersifat dinamis (waktu, tempat, sosial, dan ekonomi). Bahwa konsep gender sama dengan jenis kelamin dan hanya berkaitan dengan perempuan serta disebut sebagai urusan yang berkaitan dengan memprioritaskan perempuan. Sehingga dibutuhkan pengarusutamaan gender sebagai strategi untuk mencapai keadilan dan kesetaraan melaui kebijakan dan program.

Tidak terdapat rincian secara jelas BMN apa saja yang termasuk dalam kategori PUG. Namun, berdasarkan form evaluasi tahun 2020 berikut daftar fasilitas BMN pendukung PUG yang dimiliki KPKNL Surakarta

Tabel 2 Fasilitas BMN Pendukung PUG

\begin{tabular}{|l|c|c|}
\hline \multicolumn{1}{|c|}{ Fasilitas BMN PUG } & Eksistensi & Jumlah \\
\hline Ruang Laktasi & Ada & 1 \\
\hline $\begin{array}{l}\text { Toilet terpisah untuk } \\
\text { pegawai laki-laki dan } \\
\text { perempuan serta } \\
\text { stakeholder }\end{array}$ & Ada & 3 \\
\hline $\begin{array}{l}\text { Anak tangga ramah } \\
\text { bagi laki-laki dan } \\
\text { perempuan }\end{array}$ & Ada & - \\
\hline $\begin{array}{l}\text { Lift ramah disable } \\
\text { person }\end{array}$ & Tidak Ada & - \\
\hline \begin{tabular}{l} 
Ruang Ramah Anak \\
\hline
\end{tabular} & Ada & 1 \\
\hline
\end{tabular}

\begin{tabular}{|l|c|c|}
\hline $\begin{array}{l}\text { Media komunikasi, } \\
\text { informasi, dan edukasi } \\
\text { (KIE) tentang PUG }\end{array}$ & Tidak ada & - \\
\hline Jalur khusus kursi roda & Ada & 1 \\
\hline Parkir khusus difabel & Tidak ada & - \\
\hline $\begin{array}{l}\text { Parkir khusus } \\
\text { perempuan }\end{array}$ & Ada & 1 \\
\hline
\end{tabular}

Terdapat beberapa perbedaan pada fasilitas tersebut dengan kondisi saat penelitian ini ditulis. Yaitu ruang laktasi tampak tidak dimanfaatkan secara maksimal, bahkan tampak tidak digunakan. Kulkas yang seharusnya dapat digunakan sebagai penyimpanan ASIP terletak di pantry.

Toilet terpisah hanya ada sepasang untuk pegawai laki-laki dan perempuan, tetapi toilet lainnya termasuk bagi stakeholder menyatu antara laki-laki dan perempuan. Karena adanya pembangunan, ruang ramah anak atau pojok bermain anak sementara tidak dapat digunakan, pun akibat covid19 penggunaan ruang ramah anak memang tengah dihindari.

Yang menarik adalah ruang parkir bagi pegawai dan pengunjung. Parkir khusus difabel dan parkir khusus perempuan terdampak pembangunan sehingga batas area parkirnya menjadi saru. Berdasarkan hasil wawancara, keberadaan lahan parkir khusus wanita memang tidak berjalan efektif karena siapa yang duluan datang dapat menempati area parkir tersebut. Sedangkan fasilitas lain, seperti jalur ramah disabiitas, kursi roda, dan anak tangga ramah laki-laki dan perempuan masih berfungsi dengan baik dan sebagaimana mestinya.

\subsection{Kendala Implementasi PUG Melalui BMN di KPKNL Surakarta}

Implementasi atas kebijakan pengarusutamaan gender mengandung prasyarat yang meliputi komitmen, kebijakan anggaran, kelembagaan, tersedia sumber daya manusia, data terpilah menurut jenis kelamin, alat analisis gender, dan partisipasi masyarakat. Namun, terdapat beberapa rintangan yang ditemukan dari hasil observasi dan wawancara terhadap kesejalanan konsep pengarusutamaan gender dengan realita.

\section{a. Kurangnya Komitmen}

Terdapat kendala komitmen penyelenggaraaan pengarusutamaan gender sebagai suatu hal yang bersifat kontinu. Berdasarkan wawancara, pada tahun 2018 dan 2019, PUG memang gencar 
DINAMIKA PENGELOLAAN BARANG MILIK NEGARA BERWAWASAN GENDER (STUDI KASUS KANTOR PELAYANAN KEKAYAAN dan LEKANG SURAKARTA)

Shafira Zahdanti ${ }^{1}$ dan Taufik Raharjo ${ }^{2}$

disosialisasikan. Namun, sejak tahun 2020 program tersebut dapat dikatakan mulai redup. Padahal sebagai salah satu skala prioritas nasional, komitmen dan ketelatenan sangat diperlukan terutama dari atasan. Masalah komitmen ini juga diungkapkan oleh Narasumber 2,

"Satu, anggaran. Kedua, komitmen. Jadi seandainya pimpinan menginstruksikan ini, harus disediakan ini, kita mau tidak mau menyediakan mbak. Ketiga, kesadaran. Oh ya, satu lagi mbak. Karena ini ada di $P M K$, seharusnya pemerintah pusat membuat standar. Misal, ruang laktasi harus ada ini, ini, ini. Nah, kita disuruh bikin daftar kantor mana yang belum memenuhi sehingga otomatis tahun depan dianggarin. Sedangkan sekarang dari pusat belum maksimal."

Pada media komunikasi, informasi, dan edukasi KPKNL Surakarta yang berupa brosur mengenai PUG terdapat penjelasan mengenai konsep gender pada gambar 1, sedangkan hal tersebut dalam berkas sosialisasi PUG merupakan sebuah kerancuan dalam konsep gender sebagaimana gambar 1 dan gambar 2 . Hal ini menimbulkan perbedaan penafsiran terhadap media KIE sendiri.

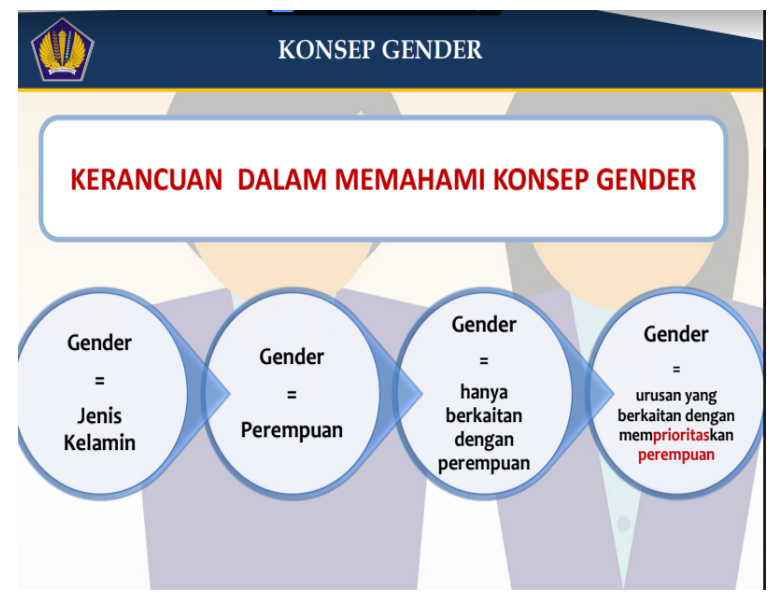

Gambar 1

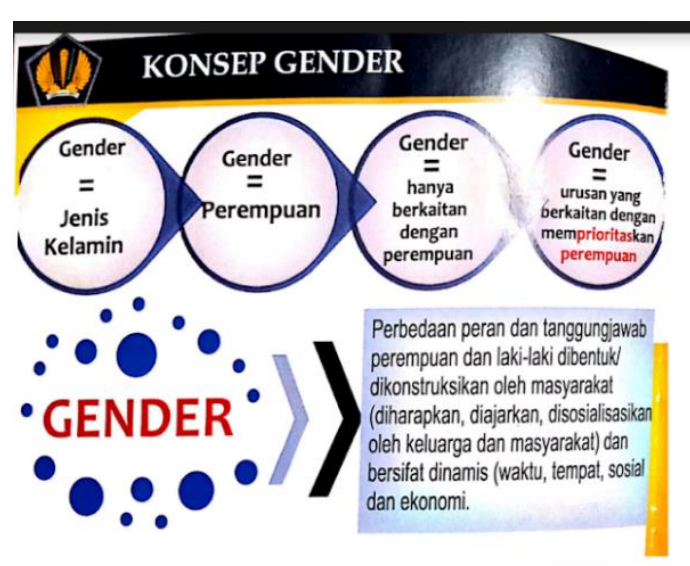

Gambar 2
Jurnal Indonesia RICH, Vol. 2, No. 1, (2020), 41 - 48

Dalam kegiatan wawancara masih terdapat beberapa pegawai yang kurang sejalan dengan konsep dari penyelenggaraan PUG. Hal ini diungkapkan oleh Narasumber 4,

"Kesetaraan gender tidak hanya mengenai perempuan setara dengan laki-laki. Biasanya perempuan dianggap lebih lemah dari laki-laki jadi bagaimana caranya supaya perempuan tidak dianggap lemah, jadi untuk memudahkan perempuan untuk setara dengan laki-laki. Nggak juga, sih. Jujur, saya pribadi kurang setuju dengan kesetaraan gender karena pada dasarnya perempuan dan laki-laki memang berbeda. Kayak pengadaan laptop di PUG kita minta laptop jangan terlalu berat agar tidak membebankan cewek. Lha gimana? Orang kita yang minta setara, tetapi malah minta dibedakan. Kan, jadinya double standard. Bukan di sini, sih. Di tempat lain, tapi di Kementerian Keuangan."

Padahal dengan arah yang sejalan dapat membantu peningkatan komitmen dari seluruh jajaran pegawai di KPKNL Surakarta. Sekaligus menghindari terjadinya permasalahan atau kontra, seperti dikatakan Narasumber 1,

"Seharusnya sudah tidak ada kontra dalam penerapan PUG pada BMN. Dikarenakan pengadaan $B M N$ dalam rangka menunjang implementasi PUG pada suatu kantor sudah didasari pada aspirasi, kebutuhan, dan permasalahan pegawai pada kantor tersebut."

\section{b. Kendala Kebijakan Perencanaan}

Suatu kebijakan dapat dituangkan ke dalam bentuk peraturan, strategi, program, panduan, juklak, juknis, dan lain sebagainya. KPKNL Surakarta merupakan sebuah kantor dengan struktur bangunan yang sudah jadi, walaupun sekarang masih dalam perbaikan dan renovasi.

Permasalahan yang mungkin persis dialami oleh kantor-kantor lain seperti KPKNL Surakarta adalah kesulitan untuk penyediaan fasilitas tertentu, sementara gedung dan bangunannya sudah terbangun serta didesain sedemikian rupa.

Terdapat fasilitas BMN tertentu dalam PUG yang membutuhkan area, seperti ruang laktasi, parkir prioritas, toilet terpisah, mushola terpisah, jalur dan lift ramah disabilitas, pojok bermain anak, tangga ramah perempuan dan laki-laki, serta poliklinik. Ketika fasilitas tersebut memang diperintahkan 
DINAMIKA PENGELOLAAN BARANG MILIK NEGARA BERWAWASAN GENDER (STUDI KASUS KANTOR PELAYANAN KEKAYAAN dan LEKANG SURAKARTA)

Shafira Zahdanti ${ }^{1}$ dan Taufik Raharjo ${ }^{2}$

pengadaannya, maka perlu dilakukan pembangunan kembali atau renovasi. Sebagaimana diungkapkan oleh Narasumber 2 selaku bagian umum,

"Struktur bangunan yang dulu desainnya tidak ada untuk itu. Kan ruang laktasi harusnya di depan, tidak mungkin di belakang. Denah bangunan yang tidak memuat ruangan laktasi atau ruang bermain anak. Kan kalau boleh jujur, ruang bermain anak itu lebih bagus untuk lelang. Makanya kita kasih dikit karena harus ada."

Narasumber 3 mengungkapkan hal yang serupa,

"Permasalahan adalah terbatasnya sarana ruang untuk mewujudkan sarana tersebut hal ini karena sejak awal BMN tidak didesain adanya fasilitasfasiltas tersebut."

Kementerian Keuangan menerapkan anggaran responsif gender. Bahkan, kantor yang akan mendirikan gedung atau bangunan baru harus responsif gender. Akan tetapi, berdasarkan hasil wawancara tidak ada peraturan tertulis mengenai BMN yang diperlukan sebagai bentuk responsif gender secara detail. Tidak ada penjelasan mendetail tentang aset BMN apa saja yang perlu dilakukan pengadaan untuk sebuah ruang laktasi, tangga yang seperti apa dapat dikatakan sebagai tangga ramah perempuan dan laki-laki, aset BMN apa saja yang diperlukan untuk sebuah pojok bermain anak, dan lain sebagainya.

Permasalahan lain mengenai pengadaan aset BMN yang mendukung terselenggaranya PUG adalah mengenai peletakan fasilitas. Di KPKNL Surakarta, pegawai perempuan meletakkan ASIP-nya di dalam kulkas yang terletak di ruang pantry, bukan di ruang laktasi, seperti yang dikatakan oleh Narasumber 4,

"Kalau kemarin karena pumping, bermanfaat. Kulkasnya ada di pantry."

Tidak ada kebjiakan peletakan dimana seharusnya ruang laktasi dan fasilitas BMN yang mendukung PUG lain seharusnya berada. Akibatnya, terutama ruang laktasi menjadi fasilitas yang sekadar ada dengan pemanfaatan yang kurang optimal.

Khususnya, ruang laktasi terkesan minim fasilitas BMN yang mendukung untuk sekadar menyusui atau pumping. Hanya terdapat satu sofa panjang dan exhaust fan. Tidak ada BMN berupa kulkas, wastafel, berikut BMN lainnya yang dapat mendukung PUG dapat terselenggara sebagaimana telah disebutkan bahwa tidak ada keterangan BMN apa saja yang diperlukan untuk sebuah pengadaan fasilitas PUG.
Fasilitas BMN lainnya yang menjadi permasalahan adalah tempat ibadah berupa mushola. KPKNL Surakarta tidak menyediakan fasilitas mushola terpisah, tetapi terdapat sebuah mushola di depan kantor dan mushola kecil di area kantor bagian belakang. Sayangnya, BMN berupa mushola tersebut kurang memadai. Khususnya, area wudhu. Tidak ada sekat bagi perempuan untuk melaksanakan wudhu secara tertutup dan aman.

\section{c. Kendala Kelembagaan}

Suatu implementasi memerlukan dukungan struktur dan kelembagaan berupa Tim Pengarusutamaan Gender, Focal Point, Sekretariat Perencanaan dan Penganggaran yang Responsif Gender (PPRG). Kementerian Keuangan tidak memiliki struktur resmi, melainkan hanya berupa tim dalam penyelenggaran PUG yang juga diterapkan pada setiap unit vertikal Kementerian Keuangan.

KPKNL Surakarta memiliki Tim PUG yang terbit melalui Surat Keputusan pada tahun 2018. Kebijakan mutasi bagi pegawai Kementerian Keuangan menyebabkan posisi tim menjadi berubah. Antara SK Tim PUG Tahun 2018 dan SK Tim PUG Tahun 2019 pun terdapat perubahan, baik pihak-pihak yang menjadi Tim PUG hingga nama bidang-bidang dalam tim PUG. Tahun 2019, PUG melibatkan lebih banyak pegawai sebagai timnya. Sayangnya, tahun 2020 dan 2021 belum ada SK terkait Tim PUG tersebut.

Berdasarkan hasil wawancara didapati bahwa tidak seluruh pegawai yang berada dalam struktur tim tersebut telah sejalan konsep dan prinsipnya dengan arah pengarusutamaan gender. Argumen yang diutarakan adalah bahwa program tersebut seringkali menimbulkan double standard, mengistimewakan perempuan, dan menuntut setara pada suatu hal yang memang sedari awal sudah berbeda, seperti argumen Narasumber 4,

"Tidak perlu double standard. Namanya, ingin disetarakan dengan cowok ya tidak usah minta fasilitas. Cowok pakai apa ya udah pakai aja."

Sedangkan, apabila memang ingin setara perempuan butuh ruang laktasi, maka laki-laki sedianya dilakukan pengadaan smoking area. Hal ini disuarakan oleh Narasumber 2,

"Gak tahu saya, tapi kalau mau setara, maksudnya kan kalau cewe mau menyusui di situ kalau ngga ada yang hamil tetap disediakan. Ya, sama. Cowok kalau ada yang merokok ya disediakan. Kita kan tidak dapat memprediksi. Saya rasa untuk menyetarakan gender kedua fasilitas tersebut harus disediakan. Termasuk tempat parkir. Menurut saya pribadi, 
DINAMIKA PENGELOLAAN BARANG MILIK NEGARA BERWAWASAN GENDER (STUDI KASUS KANTOR PELAYANAN KEKAYAAN dan LEKANG SURAKARTA)

Shafira Zahdanti ${ }^{1}$ dan Taufik Raharjo ${ }^{2}$

seharusnya tidak dibedakan perempuan dan laki-laki, difabel saja."

\section{d. Sumber Daya Manusia}

Implementasi PUG memerlukan sumber daya manusia yang peka, paham, dan terampil dalam melakukan analisis gender. Namun, beberapa pegawai masih kurang menaruh perhatian terhadap aset $\mathrm{BMN}$ yang mendukung PUG. Seperti ruang laktasi, kadang digunakan oleh pegawai laki-laki untuk beristirahat. Pada dasarnya, memang tidak banyak pegawai perempuan yang hamil dan menyusui di saat yang bersamaan. Jadi, ketika fasilitas ruang laktasi jarang digunakan merupakan suatu hal yang wajar. Namun, hal tersebut menyebabkan pegawai perempuan merasa sungkan untuk menggunakan fasilitas BMN di ruang laktasi. Lebih lagi tidak terdapat tirai di ruang laktasi, sehingga ketika pintu dimasuki seluruh area di ruang laktasi dapat terlihat. Argumen tersebut diutarakan oleh Narasumber 4,

"Ruang laktasi banyak digunakan bapak-bapak untuk istirahat karena sekarang tidak ada yang memakai. Kenapa nggak dipakai ibu-ibu aja? Ibu-ibu nggak pernah loh pakai untuk istirahat di situ. Seharusnya, kalau mau dipakai ya untuk ibu-ibu saja. Sesuai tujuannya."

Berdasarkan hasil wawancara pula diketahui bahwa proses pengadaan BMN yang mendukung PUG harus melalui perencanaan anggaran untuk kemudian diajukan. Ketika suatu BMN tidak ada atau kurang memadai, artinya memang tidak dilakukan pengajuan atau belum disetujui oleh pihak atasan. Padahal masih terdapat beberapa fasilitas yang asetnya kurang memadai demi terselenggaranya PUG.

\section{e. Penganggaran}

Perwujudan data terpilah berguna dalam penyusunan prasyarat pengarustamaan gender lainnya, yaitu analisis gender berupa Gender Budget Statement (GBS) dan formulasi kebijakan responsif gender melalui Penyusunan Penganggaran Responsif Gender (PPRG) dengan alat analisis Gender Analysis Pathway (GAP).

\section{f. Partisipasi masyarakat}

Berdasarkan hasil observasi, masyarakat atau satuan kerja cenderung jarang sekali yang menggunakan fasilitas BMN di ruang laktasi. Atas kendala tersebut Narasumber 1 memberikan keterangan,

"Apabila tidak terdapat pegawai atau stakeholder yang menyusui tapi terdapat ruang laktasi pada suatu kantor, sebaiknya ruangan tersebut dapat dimanfaatkan menjadi ruangan lain yang tepat sasaran sesuai kebutuhan dan permasalahan pegawai di kantor tersebut. Ruangan tersebut mungkin dapat diperbaiki menjadi ruang istirahat pegawai ataupun ruang co-working space."

Walaupun jarang, tetapi penggunaan $\mathrm{BMN}$ yang mendukung PUG cukup membantu bagi karyawan di KPKNL Surakarta. Sebab, berdasarkan hasil wawancara fasilitas PUG yang dianggap paling bermanfaat adalah ruang menyusui atau ruang laktasi, sebagaimana diungkapkan oleh seluruh Narasumber. Berdasarkan wawancara dengan Narasumber 4 pula terdapat alasan mengenai kurangnya pemanfaatan BMN PUG di KPKNL Surakarta,

"Mungkin masalah utamanya kalau di kantor pelayanan atau unit vertikal itu adalah seberapa sering pemakaian BMN PUG tersebut/seberapa signifikan dampaknya. Menurut pengalaman aku (pernah bekerja di kantor pusat DJKN) di kota besar seperti DKI Jakarta atau Kantor Pusat DJKN dulu, BMN PUG sangat terpakai, tapi di unit vertikal jarang sekali terpakai bisa jadi karena jarak tempuh penggunanya yang dekat dengan KPKNL atau tingkat kemacetan di kota tempat unit vertikal berada sangat rendah."

Terdapat pula jalur ramah disabilitas yang tepat berdekatan dengan parkir prioritas difabel. Sayangnya, beberapa kali ditemui area parkir tersebut tidak kosong padahal tidak ada masyarakat atau satuan kerja difabel yang datang.

\section{KESIMPULAN DAN SARAN}

\subsection{Kesimpulan}

KPKNL Surakarta telah mengimplementasikan Program Pengarusutamaan Gender di wilayah kerjanya meliputi fasilitas-fasilitas berupa BMN yang mendukung kesetaraan gender dan difabel. Fasilitas BMN tersebut ialah ruang laktasi toilet terpisah antara laki-laki dan perempuan, mushola terpisah dan ramah disabilitas, jalur dan lift ramah disabilitas, parkir prioritas ibu hamil, lansia, dan difabel, tangga ramah laki-laki dan perempuan, penyediaan sistem informasi layanan, poliklinik dan obat-obatan, serta kursi roda dan payung. Seluruh fasilitas pendukung PUG tersebut tersedia di KPKNL Surakarta sesuai imbauan Kementerian Keuangan, kecuali poliklinik, mushola terpisah, dan lift ramah disabilitas. Sejauh ini, implementasi pengarusutamaan gender melalui BMN di KPKNL Surakarta membawa dampak positif dan tidak menimbulkan pro kontra. 
Shafira Zahdanti ${ }^{1}$ dan Taufik Raharjo ${ }^{2}$

Namun, dalam praktiknya masih terdapat beberapa kendala dalam pengelolaan BMN berwawasan PUG ini, khususnya proses pengadaan dan penggunaan. Sebab tidak semua pengadaan dan penggunaan BMN tersebut telah dimanfaatkan secara optimal. Berdasarkan uraian tujuh prasyarat pengarusutamaan gender, kendala-kendala implementasi pengarusutamaan gender melalui BMN terdapat pada kurangnya komitmen, kebijakan perencanaan, kelembagaan, Sumber Daya Manusia, penganggaran, dan partisipasi masyarakat.

\section{DAFTAR PUSTAKA}

Djoharwinarlien, S. (2012). Dilema Kesetaraan Gender: Refleksi dan Respons Praksis. Yogyakarta: Center for Politics and Government (PolGov) Fisipol UGM.

Edi, S. (2016). Teori Wawancara Psikodiagnostik. Yogyakarta: Leutika Prio.

Hasanah, H. (2017). Teknik-teknik Observasi. Jurnal at-Taqaddum 8(1), 21-46.

Hayes, A., Edwards, B., \& Gray, M. (2008). Social Inclusion: Origins, concepts and key themes. Barton: Commonwealth of Australia.

Levitas, R., Pantazis, C., Fahmy, E., Gordon, D., Lloyd, E., \& Patsios, D. (2007). The Multi-Dimensional Analysis of Social Exclusion. Bristol: Bristol Institute for Public Affairs.

Rawal, N. (2008). Social Exclusion and Exclusion: A Review. Dhaulagiri Journal of Sociology and Anthropology Vol.2, 161-180.

Ruman, Y. S. (2014). Inklusi Sosial Dalam Program Kartu Jakarta Sehat (KJS) dan Kartu Jakarta Pintar (KJP) di DKI Jakarta. HUMANIORA Vol.5 No.1, 113121.

Utaminingsih, A. (2017). Gender dan Wanita Karir. Malang: UB Press.

Vasiljevic, S., Marling, R., \& Ortenblad, A. (2017). Gender Equality in a Global Perspective. New York: Routledge.

Zed, M. (2004). Metode Penelitian Kepustakaan. Jakarta: Yayasan Pustaka Obor Indonesia.

Peraturan Pemerintah Nomor 28 Tahun 2020 tentang Perubahan atas Peraturan Pemerintah Nomor 27 Tahun 2014 Tentang Pengelolaan Barang Milik Negara/Daerah.

Undang-Undang No 1 Tahun 2004 tentang Perbendaharaan Negara. 